\title{
STUDY OF COORDINATION DEVELOPMENT THROUGH PRACTICING KARATE AT THE AGE OF 12-14 YEARS
}

\author{
$\begin{array}{ll}\text { C. PETRE } & 1 \\ \text { R. ENOIU }\end{array}$
}

\begin{abstract}
This study on the development of coordination through practicing karate aims to present and demonstrate a method of coordination development through learning the basic technical procedures of traditional karate. The experiment performed on children aged between 12 and 14 years highlights the importance of coordination, which underlies their development. The practical activity specific to this martial art highlighted the development of the main components of coordination but also of the aspects related to self-control, respect, ability to concentrate and last but not least, patience.
\end{abstract}

Key words: coordination, self-control, martial arts, karate.

\section{Introduction}

The history of martial arts is not very clear given the period in which they were founded. There are a number of variants that draw a parallel between legends and reality. For a long time, practitioners were not allowed to reveal the secrets of martial arts except in the presence of the great masters during karate training [6].

The founder of the shotokan karate style is Gichin Funakoshi (1868-1957), who managed to build the foundations of modern karate, which resulted in the introduction of martial arts into the
Japanese education system. The Romanian Traditional Karate Federation was founded in 1993 and its founder is called Dan Stuparu (1951-2013) [4].

Karate is one of the most common martial arts today, practiced in over 160 countries. The popularity of this martial art is constantly growing. According to some sources, the number of practitioners exceeds 10 million, which contributed to the recognition of karate as an Olympic sport in the summer of 2020 [5].

In karate training, basic techniques are used such as: hits, blockages, dodges, which are practiced in two ways: from a

\footnotetext{
${ }^{1}$ PhD Student, Dunărea de Jos University of Galați, Faculty of Physical Education and Sport

2 Departament of Motric Performance", Transilvania University of Braşov.
} 
stationary position and with body movements in different predetermined positions. These two modes are formal and systematic in karate, representing standardized forms of predefined sequences applicable in different situations.

Traditional karate training consists of three essential components in the process of learning, consolidating and improving karate techniques.

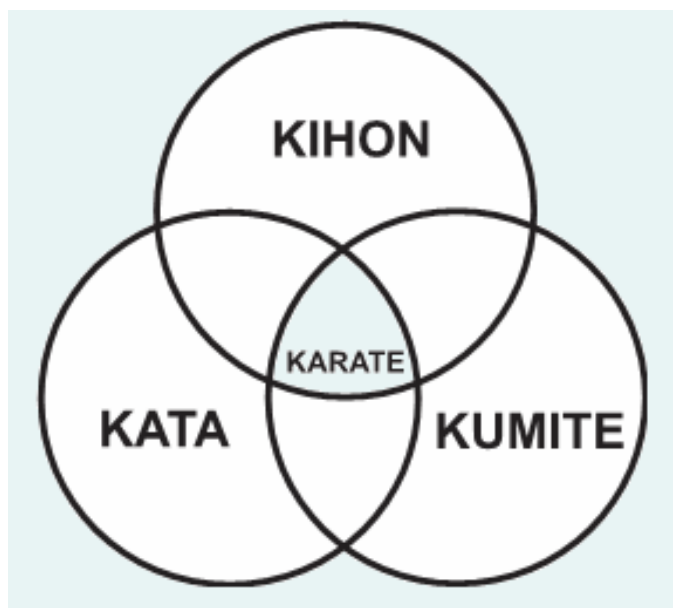

Fig. 1. The three essential components of karate

The first of these includes teaching techniques that form the basis of martial arts (Kihon). The second component of the training is based on performing a precise combination of defensive and offensive exercises, applied in a fight with several imaginary opponents (Kata). The third part (Kumite) - the fight with a real opponent was developed in the form of a karate sport only in the $20^{\text {th }}$ century.

Therefore, karate requires the application of movements with a different coefficient of complexity depending on the three mentioned components of karate. The methodical route of the three stages towards improvement is original and respects the modern theory of didactic principles. This theory involves, in the first stage, the precise execution of the exercise according to a model (first level of coordination), then the ability to link this precision with a fast execution of the movement (second level) and finally, accurate and fast demonstration of movements in various conditions (third level), which can take place during a fight with an opponent. Regarding fighting, it is very important to mention that, in traditional karate, the concept is not based on hitting the opponent in a precise place with your fist or foot, but rather on "stopping" this movement just before the impact [5].

The karate components are structured on these levels, according to table 1 . The components are correlated with other sports.

The evolution of motor skills is structured mainly around motor coordination. Primary education is one of the pillars on which the curriculum is built, not only for physical education, but also for the general education of students [3].

Coordination is "the ability of the human body to perform motor acts and actions, in various and unusual conditions, with maximum efficiency and minimum energy consumption by the performer" [1].

Cârstea G. structures the coordination in the following forms of manifestation:

- the ability to coordinate the segments of the body or its whole to perform motor acts and actions;

- the ability to combine movements;

- the ability to differentiate movements; 
- balance;

- precision;

- spatial orientation ability;

- temporal orientation ability, especially rhythm and tempo;

- amplitude, based on joint mobility - suppleness - muscle elasticity;
- ambilaterality (incompletely and incorrectly called "ambidexterity") the ability to perform motor acts and actions in all directions and planes with any upper or lower $\operatorname{limb}[2]$.

Table 1

Classification of sports disciplines according to the degree of complexity [5]

\begin{tabular}{|c|c|c|c|}
\hline \multirow{3}{*}{$\begin{array}{l}\text { The degree of } \\
\text { complexity of sports } \\
\text { disciplines }\end{array}$} & $\begin{array}{l}12 \\
11 \\
10 \\
9\end{array}$ & $\begin{array}{l}\text { III. Precision and } \\
\text { moving speed in } \\
\text { changing } \\
\text { conditions }\end{array}$ & $\begin{array}{l}\text { 1. Ice and roller hockey } \\
\text { 2. Handbal, basketball } \\
\text { 3. Football } \\
\text { 4. Volleyball } \\
\text { 5. Judo, wresling } \\
\text { 6. Traditional karate: fighting (kumite) } \\
\text { 7. Greco-Roman battles } \\
\text { 8. Frencing } \\
\text { 9. Table tennis } \\
\text { 10. Field tennis, badminton } \\
\text { 11. Kayaking, alpine skiing } \\
\text { 12. Cycling } \\
\text { 13. Ski jumping }\end{array}$ \\
\hline & $\begin{array}{l}7 \\
6\end{array}$ & $\begin{array}{l}\text { II. Precision and } \\
\text { moving speed }\end{array}$ & $\begin{array}{l}\text { 14. Traditional karate: kata } \\
\text { 15. Figure skating } \\
\text { 16. Gymnastics } \\
\text { 17. Acrobatics } \\
\text { 18. Diving } \\
\text { 19. Rhythmic gymnastics } \\
\text { 20. Cycling track } \\
\text { 21. Speed skating } \\
\text { 22. Dumbbells } \\
\text { 23. Skating: forms on ice }\end{array}$ \\
\hline & $\begin{array}{l}3 \\
2 \\
1\end{array}$ & $\begin{array}{l}\text { I. Movement } \\
\text { precision }\end{array}$ & $\begin{array}{l}\text { 24. Tir } \\
\text { 25. Gunfire } \\
\text { 26. Skating: basic } \\
\text { 27. Roller skating: basic } \\
\text { 28. Traditional karate: combination of } \\
\text { techniques (kihon) }\end{array}$ \\
\hline
\end{tabular}




\section{Hypotheses}

If a program specific to the training of traditional karate is applied to children in the gymnasium cycle, aged 12-14 years, in extracurricular activities, it is assumed that motor quality develops - the coordination - in its specific forms of manifestation.

\section{Material and Methods}

The experiment was performed on 16 students $(8$ in the control group and 8 in the experiment group) from the I. A. Basarabescu school in Ploieşti.

The subjects of the experiment group practiced karate for 8 months. The initial testing took place before the introduction of any notion or technique regarding karate. Among the subjects of the control group, no significant sports activities were registered during this period. The final testing took place at the end of the 8 months in which the experiment group learned and practiced karate.

\subsection{Testing methods}

Matorin test - the subject sits in a position sitting close with his arms outstretched next to his body, with his feet inside a circle with a diameter of 40 centimeters. He will have to perform a jump on both legs with a turn to the left or to the right. Validation of the measurement is done if the subject lands with both feet inside the circle. This test assesses the ability of spatial and temporal orientation and dynamic balance.

Tapping test (with the hand) - the subject is in a position as easy as possible at a distance of one arm from the wall; at shoulder level, on the wall, two sheets are glued at a distance of $15 \mathrm{~cm}$ from each other. One slap is placed on the wall between the two sheets, and with the other slap, the subject must touch the sheets alternately for a period of 30 seconds. This test assesses the ability to combine movements, accuracy and rhythmic ability.

Romberg test - in this test, the subject is in a standing position with his feet close together, his arms outstretched next to his body, his eyes closed. It is measured how long it can stand still. From a medical point of view, a healthy person can maintain his balance for 30 seconds. This test evaluates the static balance and the spatio-temporal orientation.

Dynamic arm accuracy test - the subject is in the guard position. 10 table tennis balls will be thrown at him, by turn, from a distance of 3 meters, with a speed of about 4 meters per second. The subject must hit each ball with his fist. Count how many balls were punched. The test highlights the precision of the subject, spatial and temporal orientation, segmental and general coordination.

\section{Results and Discussions}

Following the tests that took place at the beginning and end of the experiments, specific results were obtained according to each form of testing.

Matorin test results - This test was measured in degrees. Both groups had similar results in the initial testing $(62.15 \%$ - 61.89\%). In the final test, the control group had a growth rate of $3.38 \%$ and the 
experiment group of $18.01 \%$. The difference of the final tests is $11.37 \%$. This result highlights the development of dynamic balance and spatial and temporal orientation.

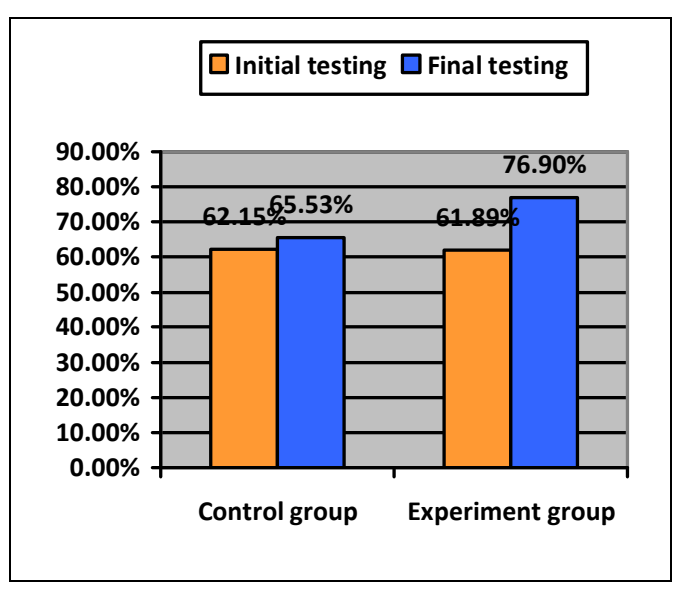

Fig. 2. Matorin test results

Tapping test results - This test was measured in number of repetitions. Both groups had similar results in the initial test (42.5 - 43.87 repetitions). In the final test, the control group had an average progress of 1.25 repetitions and the experiment group of 12.5. The difference of the final tests of the two groups is 12.62 repetitions. From this result, the progress of the coordination of the upper limbs is observed.

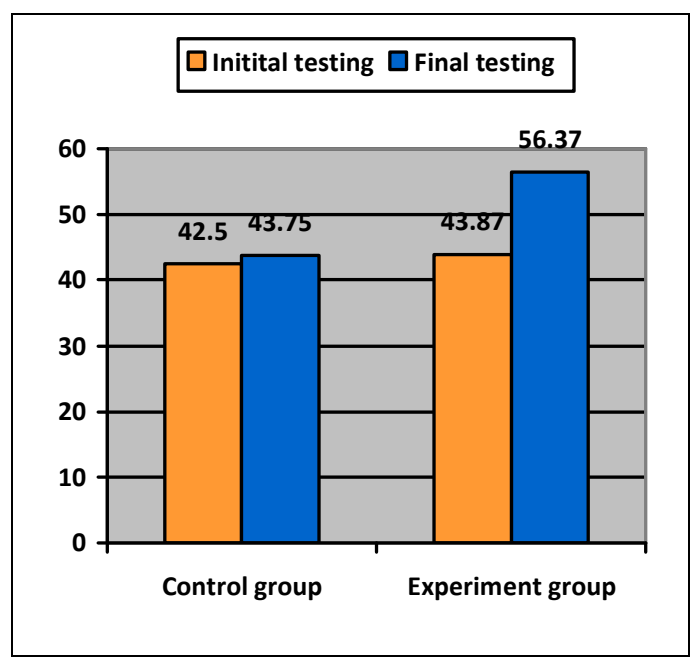

Fig. 3. Tapping test results

Romberg test results - This test is measured in seconds. Both groups had similar results in the initial test (35.8 $38.1 \mathrm{sec}$.$) . In the final test, the control$ group increased by an average of 3.13 seconds and the experiment group by 9.88 seconds. The difference of the final tests is 9 seconds. This result shows the progress in terms of static balance.

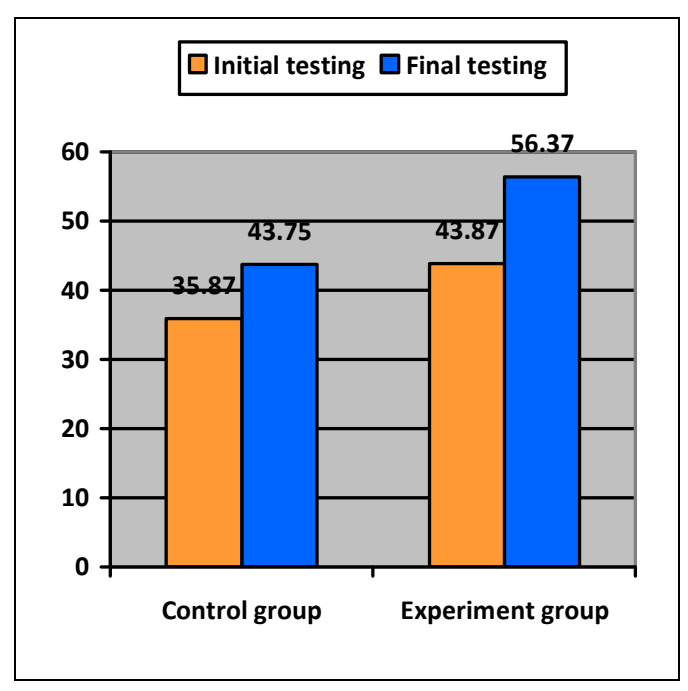

Fig. 5. Romberg test results 
Arm accuracy test results - This test is measured in number of strokes. Both groups had similar results at the initial test $(51.25 \%$ - 50\%). At the final test, the control group had an increase of $2.5 \%$ and the experiment group of $25.5 \%$. The difference of the final tests is $21.75 \%$. From this result, the development of precision in the arms is observed.

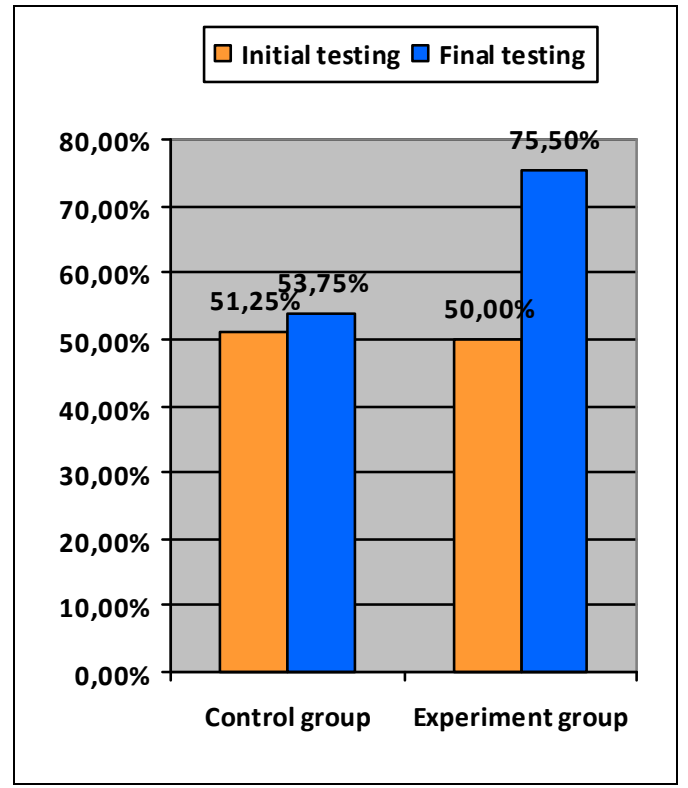

Fig. 5. Arm accuracy test results

\section{Conclusions}

Following the results of the 4 tests used to test the improvement of coordination as a result of the efficiency of karate training, all 4 tests show a significant progress in the development of coordination in subjects who practiced karate, compared to those who did not. Thus, the hypothesis is confirmed.

The greatest progress of the experiment group was registered in arm accuracy test.

\section{References}

1. Cârstea, G.: Educaţia fizică - teoria şi bazele metodicii (Physical education theory and basics of methodology). București, Editura ANEFS, 1997, p. 100

2. Cârstea, G.: Teoria şi metodica educaţiei fizice şi sportului (Theory and methodology of physical education and sports). București, Editura AN-DA, 2000, p. 56

3. Cezino, J.M., Ramirez, J.M., Ravelo, J., Fernandez, J.C.: Assessment of motor coordination in students aged 6 to 11 years. In: Journal of Physical Education and Sport, Vol. 15, 2015, p. 765-774, DOI:10.7752/jpes.2015.04117

4. Herta, S.: Karate: artă, frumusețe, armonie (Karate: art, beauty, harmony). Cluj, Editura Napoca Star, 2019.

5. Starosta, W., Pawłowa, T.: Level of selected movement coordination abilities in different trainings periods in athletes Polish National Team of Traditional Karate, In: Journal of Combat Sports and Martial Arts, Vol. 2, 2011, p. 95-101, DOI:10.5604/20815735.1047141

6. Țichindelean, D.: Karate do shotokan, o viață dedicată artelor marțiale(Karate do shotokan, a life dedicated to martial arts). Sibiu, Editura D\&T Advertising, 2010, p. 9. 